\section{EPISTEMOLOGICAL STUDIES IN PHILOSOPHY, SOCIAL AND POLITICAL SCIENCES \\ ISSN 2618-1274 (Print), ISSN 2618-1282 (Online) \\ Journal home page: https://visnukpfs.dp.ua/index.php/PFS/index}

\author{
Марія Анатоліївна Міхейченко \\ Кандидат політичних наук, доцент \\ Доцент кафедри міжнародних відносин \\ Дніпровський національний університет \\ імені Олеся Гончара \\ Пр. Гагаріна 72, Дніпро, 49000, Україна \\ E-mail mikheichenko.mariia@gmail.com, ORCID ID: https://orcid.org/0000-0002-1536-1357 \\ Mariia Mikheichenko \\ $\mathrm{PhD}$ in Political science, Assoc. Prof. \\ Assoc. Prof. of the Department of \\ International Relations \\ Oles Honchar Dnipro National University \\ Gagarina Ave., 72; Dnipro, 49000, Ukraine
}

УДК 327:001.4

\title{
ГРОМАДСЬКЕ ЗАЛУЧЕННЯ У НІМЕЧЧИНІ \\ В УМОВАХ ГЛОБАЛЬНОГО РОЗВИТКУ
}

Received 12 August 2019; revised 18 September 2019; accepted 18 October 2019

DOI: $10.15421 / 341930$

\begin{abstract}
Анотація
Вивчаються технологї та форми громадського залучення на прикладі сучасної Німеччини. Розкриваються особливості громадського залучення, зокрема участь у волонтерській діяльності. Наголошується на наявності диференщіації різноманітних форм громадської взаємодії, що охоплюють всі сфери суспільного буття. Підкреслюється значення добровільної громадської участі та ії впливу на внутрішню та зовнішню політику країни, на міжнародні відносини загалом. Окреслено історичні віхи розвитку громадської участі у сучасній Німеччині.

Доводиться, що громадянське залучення - ие прочес, в якому громадяни здійснюють колективні дї для вирішення питань, що становлять суспільний інтерес і сприяють демократії. Наголошується, щзо громадське залучення вирішує низку суспільних проблем, серед яких, зокрема, недостатнє представлення різноманітних груп інтересів, тим самим знижуючи рівень суспільної напруги у суспільстві. Підкреслюється, що розуміння всіх варіантів громадянської участі розвиває «демократію різноманітності», що визначається як спосіб впливати на рішення влади у міжвиборчий період. Наголошується на необхідності проведення заходів із інформування громадян про події та явища суспільно-політичного жсття. 3'ясовано, щзо інтенсифікацію демократизації посттоталітарних суспільств спричиняе ступінь розвитку громадського залучення у вирімення суспільно-політичних проблем. Нові агенти впливу - громадяни, щзо є залученими до різних форм взаємодії виступають носіями нової партисипаторної демократії, щзо веде до стабілізації політичної, економічної систем та міжнародної системи загалом. Визначається, що чинниками до лобіювання громадської участі, що призведе до подолання іррачіональності і пасивності людей в політичній сфері - є освіта і надання рівних можливостей для участі в політиці. Тому кожному суспільству належить створити всі умови для активної політичної сочіалізачії кожного індивіда.

3'ясовано, що у політичному діалозі та прийнятті рішень громадське залучення допомагає стримувати конфлікти, щзо виникають через непорозуміння у сторін, сприяючи встановленню конструктивного діалогу міжнародних акторів у сучасній системі міжнародних відносин.
\end{abstract}

Ключові слова: громадська участь, громадське залучення, Німеччина, волонтерство, громадська дія, конструктивний діалог, система міжнародних відносин.

\section{Civic engagement in Germany in terms of Global Development Processes}

\section{Abstract}

Technologies and forms of civic engagement on example of contemporary Germany are studied. The features of civic engagement, including participation in volunteer activities, are revealed. The differentiation of various forms of social interaction, covering all spheres of social life is revealed. The importance of voluntary public participation and its influence on the domestic and foreign policy of the country and on international relations is emphasized. The historical milestones of the civic engagement development in contemporary 
Germany are outlined.

It is argued that civic engagement is a process in which citizens take collective actions to address issues of public interest and democracy. It is emphasized that civic engagement solves a number of societal problems, including, in particular, the lack of representation of diverse interest groups, thereby reducing the level of social tension in society. It is emphasized that understanding of all options for civic participation develops a "democracy of diversity", which is defined as a way to influence the decisions of the authorities in after election period. It is emphasized on the need to take measures to inform citizens about the events and phenomena of social and political life. It has been found that the intensification of the democratization of post-totalitarian societies causes a degree of public involvement in the solution of socio-political problems. New Agents of Influence - Citizens involved in various forms of engagement are the bearers of a new democracy, leading to the stabilization of the political, economic and international systems in general. It is determined that the factors for lobbying civic engagemement, which will lead to overcoming the irrationality and passivity of people in the political sphere - are education and providing equal opportunities for participation in politics. Therefore, every society has to create all conditions for active political socialization of each individual.

It has been found that in political dialogue and decision-making, public involvement helps to curb conflicts arising from misunderstanding between the parties, facilitating the establishment of a constructive dialogue of international actors in the current system of international relations.

Key words: civic engagement, civic involvement, Germany, volunteering, civic action, constructive dialogue, system of international relations.

\section{Гражданское участие в Германии в условиях глобального развития} Аннотация

Изучаются технологии и формы общественного привлечения на примере современной Германии. Раскрываются особенности общественного привлечения, в том числе участие в волонтерской деятельности. Отмечается наличие дифференциачии различных форм общественного взаимодействия, охватываюших все сферы общественного бытия. Подчеркивается значение добровольного общественного участия и его влияние на внутреннюю и внешнюю политику страны, на международные отномения в иелом. Определены исторические вехи развития общественного участия в современной Германии.

Доказывается, что гражданское привлечение - это прочесс, в котором граждане осуществляют коллективныедействия длярешениявопросов, представляющихобщественныйинтересиспособствуют демократии. Отмечается, что общественное привлечения решает ряд сочиальных проблем, среди которых, в частности, недостаточное представление различных групп интересов, тем самым снижая уровень общественного напряжения в обществе. Подчеркивается, что понимание всех вариантов гражданского участия развивает «демократию разнообразия», которая определяется как способ влиять на решения власти в период между выборами. Подчеркивается необходимость проведения мероприятий по информированию граждан о событиях и явлениях общественно-политической жизни. Выяснено, что интенсификацию демократизации посттоталитарных обществ вызывает степень развития общественного вовлечения в решение общественно-политических проблем. Новые агенты влияния - граждане, являются привлеченными к различным формам взаимодействия, выступают носителями новой партисипаторной демократии, что ведет $\kappa$ стабилизации политической, экономической систем и международной системь в иелом. Определяется, что факторами к лоббированию общественного участия, что приведет к преодолению иррациональности и пассивности граждан в политической сфере - есть образование и предоставление равных возможностей для участия в политике. Поэтому каждому обществу предстоит создать все условия для активной политической сочиализачии каждого индивида.

Установлено, что в политическом диалоге и принятии решений общественное привлечение помогает сдерживать конфликтьи, возникающие из-заразногласийусторон, способствуяустановлению конструктивного диалога международных акторов в современной системе международных отномений.

Ключевые слова: гражданское участие, общественное привлечение, Германия, волонтерство, гражданское действие, конструктивный диалог, система международных отношений. 


\section{Постановка проблеми.}

За умов глобалізованого світу, із поглибленням процесів інтеграції та регіоналізації, iз зростаючим чинником протистояння представників різних цивілізацій, що за словами Семюела Хантінгтона $є$ неодмінною характеристикою теперішнього світу, все більшої уваги заслуговують дослідження, що спрямовані на пошук нових практик та конструктів буття різних спільнот у сучасній системі міжнародних відносин на основі демократичних принципів та розвитку громадянського суспільства.

На сьогодні в багатьох країнах світу до політичної еліти приходить розуміння того, що встановлення діалогу із громадськістю (як на національному рівні, так і на світовому) із вирішення суспільно-важливих питань та залучення членів громади до публічної сфери політики є неодмінною запорукою успішного розвитку демократичного суспільства. Встановлення діалогу з громадськістю не обмежується суто розвитком комунікативних практик та трансляцією меседжів за для впливу на світову громадськість. Актуалізується проблематика низької довіри до дій як національних урядів, так і міжнародних організацій, діяльність яких спрямована на мінімізацію ризиків вайлентизації політики, винайденню превентивних механізмів протидії таким явищам міжнародного життя як міжнародний тероризм, міграційна криза, глобальне безробіття i т.п. Відповіддю на численні виклики сучасного глобалізованого світу на сьогодні може слугувати нова модель розвитку суспільства, в якій на базі відтворення конструкту поваги до демократичних цінностей надається можливість усім членам громади залучитися до прийняття політичних рішень, до вирішення суспільно-важливих рішень. Дане суспільство має розвивати практики громадського залучення за для досягнення максимального ефекту загального блага для всіх членів суспільства та попередженню конфліктних ситуацій.

\section{Аналіз публікацій.}

Проблематику громадського залучення досліджували такі дослідники як доцент Центру громадської та соціальної політики Південно-Західної Флориди, Університету Фло104 риди Маргарет Баньян. Так, доктора Баньян, можна по праву вважати контрибутором із тлумачення змісту громадської участі в сучасному глобалізованому світі [Banyan 2016]. На прикладі конкретних суспільств практики громадського залучення вивчалися дослідником Клейном А., який диференціював приклади громадського залучення у Німеччині [Klein 2016]. Серед вітчизняних дослідників проблематику громадської участі вивчали Сергієнко O., Ватаманюк О., зокрема надавали дефініції та розкривали форми та види громадського залучення на прикладі сучасної України [Сергієнко \& Ватаманюк 2016]. Дослідники Карий O.I., Панас Я.В. у своїх роботах визначали громадське залучення крізь призму пошуку ефективних механізмів місцевого самоврядування [Карий \& Панас 2015]. Однак, слід констатувати відсутність комплексного дослідження впливу практик громадського залучення на сучасні міжнародні відносини за умов глобального розвитку. Здійснення даного дослідження є надзвичайно актуальним, адже в умовах зростаючих ризиків міжнародного терроризму, вбачається актуальним пошук превентивних технологій протистояння глобальним викликам та загрозам.

\section{Постановка завдання.}

У дослідженнях західних дослідників зазвичай розрізняють два терміни - «громадська участь» (civic participation), «громадське залучення» (civic engagement), якими позначають явище індивідуальної, або групової активності за для вирішення суспільно-важливих питань, або змін у громаді. Отже, концепт «громадського залучення» означає автоматичну зміну життя громади та розвиток і поєднання знань, умінь, цінностей та мотивації, спрямованих на фасилітацію цих змін. Це означає підвищення якості життя в громаді через політичні та неполітичні процеси. У сучасному глобалізованому світі, що перебуває на етапі трансформації багатьох суспільно-важливих структур, вивчення світового досвіду розвитку громадського залучення також вбачається надзвичайно актуальним питанням. Вироблення превентивних технологій, спрямованих на зменшення кількості конфліктних ситуацій, збройних 
протистоянь, територіальних суперечок, пошук механізмів співпраці у межах діяльності міжнародних організацій на сьогодні є ключовим питанням світового порядку денного. Особливої гостроти дана проблематика набула під час міграційної кризи у країнах $€ C$, із посиленням конфліктних протистоянь та діяльності міжнародних збройних угрупувань на Близькому Сході та нестабільною політичною та економічною ситуацією у низці країн Африканського континенту. Посилення диспропорцій у світовому розвитку, намагання міжнародних акторів у будь-який спосіб збільшити свою могутність та вплив на міжнародній арені, призводить до ситуації турбулентності сучасної системи міжнародних відносин. За даних обставин вивчення громадського залучення як превентивної технології із стабілізації сучасної системи міжнародних відносин вбачається вкрай важливим фактором у підходах до вирішення даної проблеми.

\section{Виклад основного матеріалу.}

За словами американської дослідниці М.Баньян: «...Посилення громадянської активності - це складне завдання з реальними обмеженнями. Наприклад, громадянське залучення вимагає часу та ресурсів, але сучасне суспільство тягне людей у конфліктні напрямки. Крім того, багатьом громадам не вистачає соціальних та політичних інститутів, необхідних для структурування їх взаємодії, такі як діалогічні форуми чи збори громади. Підхід до взаємодії, який непропорційно покладається на громадян, які мають достатньо часу та ресурсів, ризикує віддати перевагу певним членам суспільства перед іншими. Це заохочує домінування крайніх інтересів, результатів, яких прагне уникнути громадянська участь...» [Banyan 2016].

Громадянське залучення застосовується в різних контекстах - від бізнесу до розвитку громади. Його основоположне припущення полягає в тому, що як інтелектуальна, так і орієнтована на дії участь створює соціальні та політичні зв'язки у громаді. Через процес взаємодії люди бачать себе як невід'ємну частину громади, де відбувається формування громадської думки. Це засіб для досягнення демокра- тичних цінностей рівності та врахування інтересів у розробці політики. Вважається також, що концепт громадського залучення збільшує «соціальний капітал» - ресурси, які індивід чи група отримують із взаємин визнання та співпраці.

На думку вітчизняних дослідників Сергієнка О., Ватаманюка О.: «Незважаючи на це, досвід розвинутих демократій та вимоги часу переконують, що громадська участь - це необхідний, корисний та вкрай важливий механізм позитивного впливу громадськості на діяльність влади в державі в інтересах громадян. 3 іншого боку, громадська участь - це джерело додаткового інтелектуального ресурсу для публічної влади і тому є корисною і потрібною також і для неї (звичайно, у разі усвідомлення посадовими особами цього незаперечного факту)...» [Сергієнко \& Ватаманюк 2016].

Прихильники громадянської активності приймають легітимність керівних інституцій, але прагнуть використовувати політичну та асоціативну діяльність, як формальну, так і неофіційну, як інструменти просування демократичних цінностей. Політичне залучення фокусується на заохоченні діяльності до прийняття громадських рішень, таких як голосування, участь у громадських зборах, або волонтерська діяльність для проведення різного роду кампаній. Участь в асоціаціях зазвичай заохочує волонтерство в некомерційних організаціях (на кшталт участі у благодійних акціях). Слід зауважити, що коли громадяни беруть участь на добровільній основі, багато проблем можуть бути попереджені або вирішені до поглиблення протистояння сторін, що мають різне бачення на вирішення проблемного питання.

Як підкреслюють дослідники Сергієнко О., Ватаманюк О. «... В контексті управлінської діяльності громадська участь дає змогу враховувати соціальні чинники в процесі планування, мінімізувати соціальні та політичні ризики внаслідок ухвалення та реалізації управлінських рішень, корегувати плани та поведінку влади відповідно до інтересів тих чи інших суспільних груп, а також залучати їх до процесу ухвалення управлінських рішень. 
Таким чином, громадська участь дозволяє, 3 одного боку, мінімізувати соціальні та політичні ризики, а з іншого - визначати, формулювати та відстоювати інтереси громади...» [Сергієнко \& Ватаманюк 2016].

Громадянське залучення у Німеччині характеризується високим ступенем організованості, безліччю граней та різноманітністю форм втілення. Тим не менш, наразі громадянське залучення стикається з великими змінами та викликами. Питання щодо збільшення залучених членів вже десятиліттями хвилює великі організації різних сфер суспільного буття. У багатьох областях особливо важко залучити наступні покоління, навіть за наявності мотиваційних механізмів. Основним викликом на прикладі Німеччини є досягнення більшої участі з боку людей, які мають менший досвід роботи в системі освіти або соціально незахищених, оскільки вони демонструють менші показники громадянської активності.

Понад третина населення Німеччини бере участь у якійсь формі громадської участі. Сюди входять люди, які беруть активну участь у громадянському суспільстві в одній або декількох сферах, або активно працюють як волонтери. Відповідно до статистичних даних iз волонтерства в Німеччині, репрезентативного опитування щодо волонтерської діяльності та громадської активності в Німеччині, частка тих, хто займається добровільною діяльністю за останні 14 років у Німеччині, зросла з 34\% до 36\% [Germany Human Development Report 2016].

Тож слід відзначити, що у Німеччині ще наявний потенціал до громадського залучення. За статистичними даними у Німеччині, iз $64 \%$, які ще не беруть участь у громадській діяльності, більше третини, безумовно, бажають грати активну роль. Ця частка, яка становила 26\% у 1999 році, зросла на 11\%, до 37\% у 2019 році [Germany Human Development Report 2016].

Чотири 3 десяти опитаних людей на даний момент не займаються громадською діяльністю, але були б готові зробити це відповідно за певних обставин. Вагомим мотиваційним фактором громадської участі може стати зро106 зумілість для учасників кінцевого або очікуваних результатів дій. Ці результати підтверджують, що чим детальнішою $є$ інформація щодо варіантів громадської активності, тим більшого визнання такої діяльності може мати серед громадськості.

Аналізуючи філософсько-психологічні засади громадського залучення як соціального конструкту, розуміємо, що потреба у громадському залученні походить від самої потреби людства до громадського залучення. Тобто, слід відзначити, що потреба в активній участі членів громади у їі повсякденному житті $\epsilon$ природньою. Проте, нерідко активність громадськості є низькою або дуже низькою. До визначальних чинників такого стану громад слід віднести, насамперед, ресурсний потенціал територіальної громади (інтелектуально-кадровий ресурс громад; природний ресурс; матеріально-технічний ресурс; земельний ресурс громад; інфраструктурний ресурс тощо). Аналізуючи палітру громадської участі/залучення населення Німеччини, бачимо, що спорт та фізичний відпочинок на сьогодні $\epsilon$ провідними сферами громадської активності, дуже часто позбавлені політичної складової. Школи та дитячі садки, церква та релігія, культура та музика, а також соціальний контекст також належать до числа переважаючих напрямків громадянської активності у Німеччині. Крім того, громадське залучення проявляється також у багатьох інших контекстах. Залучення до соціальних, медичних, дитячих та молодіжних сфер, а також у контексті церков / релігій, культури та навколишнього середовища помітно зростає з 1999 року у німецьких землях [Germany Human Development Report 2016].

Зауважуємо, що громадянське залучення не однаково поширене у всіх регіонах Німеччини. Отже, в останні десять років дані практики дещо збільшилися на території Східної Німеччини (з 28\% до 31\%), що можна трактувати як позитивний показник для розвитку громадянського суспільства. Проте, рівень громадської активності у Східній Німеччині нижчий, ніж у Західній (37\%). Окрім відмінностей «East-West», існує також розрив між 
Північчю та Півднем, а також міськими та сільськими районами, завдяки чому порівняно високий рівень громадського залучення може бути виявлений у сільських регіонах Південної Німеччини [Germany Human Development Report 2016].

Не всі громадяни задіяні в однаковій мірі. Можна спостерігати відмінності, пов'язані 3 соціокультурними характеристиками; до них належать освітній статус, професія, рівень доходу, вік та стать. Соціоструктурні відмінності відображаються також у різних формах взаємодії, наприклад, готовності відігравати провідну роль або робити пожертви. Власні економічні ситуації людей, їх причетність до соціальних питань, а також їх ціннісні системи мають особливо сильний вплив на їх готовність бути активними членами суспільства, залучаючись до вирішення суспільно-важливих питань. Соціоструктурні фактори також $\epsilon$ важливим фактором, що пояснюють загалом нижчий рівень довготривалої участі людей 3 історією імміграції [Civil Society Sector at a Glance: Germany 1995].

Показники громадського залучення різко зростають серед зайнятих та тих, хто має вищу освіту. Результати сучасних досліджень показують, що люди, які особливо причетні до громадської активності, - це люди, які в силу інших особливостей добре інтегруються в суспільство, мають вищий рівень освіти та більший дохід. Люди, які працюють, демонструють найвищий рівень зайнятості, внаслідок чого показник серед тих, хто працює за сумісництвом, порівняно найвищий. Залучення особливо яскраво виражено серед чоловіків, які працюють, та людей з вищим освітнім рівнем. Люди, які є безробітними, або мають низький соціальний та освітній статус, недостатньо представлені. Існує сильна кореляція між доходами та зайнятістю.

Гендерний чинник у громадському залученні також має достатньо сильну вагу, так, зокрема жінки, як правило, недооцінені в громадській активності, зокрема в таких сферах, як спорт, і особливо на керівних посадах. Як і у випадку з чоловіками, зайнятість жінок змінюється залежно від фази життя, через яку вони зараз проходять. Отже, рівень зайнятості серед жінок віком від 45 до 55 років майже такий же, як у чоловіків того ж віку. 3 іншого боку, жінки від 25 до 30 років набагато рідше беруть участь у громадській діяльності, ніж чоловіки в одній віковій групі. Можна припустити, що освіта / професійне навчання та вступ до трудового життя залишають молодим матерям, зокрема, менше часу для додаткової участі у сфері громадського залучення [Civil Society Sector at a Glance: Germany 1995].

Громадська активність зростає серед людей старшого віку та зменшується серед молодих людей.

За словами західного дослідника Ю.Габермаса: «Ліберальній політиці не варто екстерналізувати вічну суперечку про секулярне розуміння суспільства, а саме імплементувати його у голови віруючих. Демократичний просвітлений здоровий глузд не поодинокий, він описує ментальну будову багато гласної публічності. Секулярна більшість не повинна виносити рішення 3 важливих питань, перш ніж воно не врахує думки опонентів, які відчувають себе пригнобленою більшістю...» [Хабермас 2002: 45].

Сучасні дослідження показують, що громадське залучення має перспективи розвитку у відповідності із соціальними запитами людей, зокрема, вікова складова також відіграє важливу роль для громадянської активності.

Так, бачимо, що зниження показників громадської активності 3 боку молодих людей можна пояснити збільшенням їх мобільності, браком часу та реалізацією професійних завдань. Тим не менше, рівень громадської участі між 14 і 24 роками є все ще значним - 35\%, таким чином, молодь представляє суттєву груп тих, хто залучений до громадської активності. Крім того, потенціал молодих людей стосовно громадського залучення зростає. Мотиви участі молоді та молодих людей з часом змінювалися. Зараз громадянське залучення призводить до переваг у досягненні професійних цілей [Germany Human Development Report 2016].

Більшість громадських дій у Німеччині із вирішення усього спектру соціально-політич- 
них питань реалізується завдяки діяльності майже мільйона організацій. Ці у більшості випадків некомерційні організації громадського суспільства забезпечують основу для громадської активності, поєднують, просувають та формулюють інтереси, або виступають у ролі важливих постачальників послуг. Організаційні форми $\epsilon$ неоднорідними та охоплюють інститути, що різняться за фінансовими ресурсами, цільовою спрямованістю та правовою формою. Асоціації, федерації та фонди вважаються найпоширенішими організаційними формами у сфері громадської активності. Політичні партії, союзи та церкви посідають також чільні позиції. Слабко пов'язані та неофіційно організовані групи, такі як приватні ініціативи та рухи, зараз користуються підвищеною увагою, але достовірних даних немає, оскільки сучасні емпіричні соціальні дослідження нових форм участі (наприклад, у контексті Web 2.0) тільки почалися [Civil Society Sector at a Glance: Germany 1995].

Громадська участь у контексті церков та релігійних громад $\epsilon$ відносно стабільною, як за ступенем, так і за тривалістю. 14\% тих, хто бере участь у залученні до громадянського суспільства, є активно залученими, а понад дві третини - із меншою ступеню інтенсивності. Церкви у Німеччині мають значний потенціал до громадського залучення. Домінуючими $€$ традиційні форми добровільної діяльності, які $є$ альтруїстично мотивованими та тягнуть за собою довгострокові зобов'язання. Церкви також пропонують варіанти участі, які більше відповідають «новому волонтерству», що має обмежений термін і в основному приваблює молодих людей 3 міських районів цілей [Germany Human Development Report 2016].

Велика та маргіналізована суспільна група, що складається переважно 3 жінок та молоді, досі не $є$ залученою до прийняття суспільно-політичних рішень. Не зважаючи на те, що вище наведена ситуація має тенденцію до динамічного розвитку після багатьох років політичного застою, слід констатувати, що все ще бракує діалогу за участю місцевих керівників, організацій громадянського суспільства та населення загалом.

108

\section{Висновки.}

Отже, констатуємо, що Німеччина має потужну інфраструктуру громадської участі, однак наявні і чисельні виклики у розвитку громад. Більшість дослідників існуючих моделей громадського залучення у Німеччині приходять до спільного висновку, що для забезпечення ефективного громадського залучення необхідно визначити наступні пріоритети - складові порядку денного політики взаємодії: зміцнення громадянського суспільства та громадської активності; удосконалення законодавчої, інституційної та організаційної основи громадської активності; забезпечити сумісність програм та заходів щодо реформування добробуту із залученням залучених програм; стимулювати розвиток культури визнання громадянської активності; продовжувати розробляти заходи з навчання для зайнятих громадян; зміцнення місцевого громадянського суспільства; продовжувати розвивати добровільні служби; розвивати діяльність всіх організацій та установ, які беруть участь у участі та громадянській співпраці; реформувати державну адміністрацію для підтримки залучення; продовжувати сприяти залученню на рівні федеральному та на рівні регіонів; консолідація та розвиток інфраструктури для сприяння залученню на рівні місцевих органів влади; сприяти громадянській активності серед іммігрантів; зміцнення європейського громадянського суспільства; підтримка місцевих альянсів; розвиток співпраці між громадянським суспільством, бізнесом та державою; зміцнення та розвиток корпоративного громадянства в установах, підприємствах, організаціях.

Участь населення у політичному діалозі та прийнятті рішень допоможе стримувати конфлікти, що виникають через нерозуміння та відсутність налагоджених каналів комунікації та відсутність співпраці.

Створення відповідних умов на міжнародній арені, що сприяють розвитку безконфліктних громад з високим ступенем громадського залучення, призведе до стабільного соціально-політичного та економічного розвитку спільнот. 


\section{Бібліографічні посилання}

Місцеві ініціативи та залучення громадськості до здійснення місцевого самоврядування. Навчальний посібник для посадових осіб місцевого самоврядування /Карий O.I., Панас Я.В. [Електронний ресурс]. Режим доступу: https://www.auc.org.ua/sites/default/files/ library/6misiniweb.pdf.

Сергієнко, О., Ватаманюк, О. (2016). Громадська участь/залучення громадян. Депутатська діяльність в округах [Електронний ресурс]. Режим доступу: https://www.csi.org.ua/wpcontent/uploads/2016/10/Gromadskaychast.pdf.

Хабермас, Ю. (2002). Будущее человеческой природы. Пер. с нем. М.: Издательство «Весь мир», $144 \mathrm{c}$.

Banyan, Margaret E. (2016). Civic engagement. Retrived from: https://www.britannica.com/topic/civicengagement

Klein, A. (2016). Good Governance - civil society and civic engagement in Germany. Retrived from: http://agree-europe.de/images/Expertenbeitraege/Expertenbeitrag_Klein_EN.pdf

World Development Indicators. World Bank, 2009, Web. Retrived from: http://data.worldbank.org/ indicator/NY.GNP.ATLS.CD

Population Indicators, German Federal Statistical Office, Web, 25 October 2010. Retrived from: http:// www.destatis.de/jetspeed/portal/cms/

Voluntary Action in Germany: Facts and Figures, European Volunteering Center, Web, 25 October 2010. Retrived from: http://www.icicp.org/ht/a/GetDocumentAction/i/5534.

Civil Society Sector at a Glance: Germany, 1995," Center for Civil Society Studies, Johns Hopkins University. Retrived from: http://www.ccss.jhu.edu/pdfs/CNP/CNP_Germany_WrkExp.pdf

Germany Human Development Report, United Nations Development Programme, 2007/2008. Retrived from: http://hdrstats.undp.org/countries/data_sheets/cty_ds_DEU.html.

\section{References}

Miscevi iniciaty`vy' ta zaluchennya gromads'kosti do zdijsnennya miscevogo samovryaduvannya. Navchal'ny`j posibny`k dlya posadovy`x osib miscevogo samovryaduvannya /Kary`j O.I., Panas Ya.V. [Local initiatives and civic engagement in local government. A guide for local government officials]. Retrived from https://www.auc.org.ua/sites/default/files/library/6misiniweb.pdf (In Ukrainian).

Sergiyenko, O., Vatamanyuk, O. Gromads 'ka uchast`/zaluchennya gromadyan. Deputats 'ka diyal’nist` v okrugax [Civic engagement / citizen involvement. Deputy activities in districts]. Retrived from: https://www.csi.org.ua/wp-content/uploads/2016/10/Gromadskaychast.pdf (In Ukrainian).

Habermas, Yu. Buduschee chelovecheskoy prirodyi [Future of human nature]. Per. s nem. M.: Izdatelstvo «Ves mir», 2002. 144 s. (In Russian).

Banyan, Margaret E. (2016). Civic engagement. Retrived from: https://www.britannica.com/topic/civicengagement.

Klein, A. (2016). Good Governance - civil society and civic engagement in Germany. Retrived from: http://agree-europe.de/images/Expertenbeitraege/Expertenbeitrag_Klein_EN.pdf.

World Development Indicators. World Bank, 2009, Web. Retrived from: http://data.worldbank.org/ indicator/NY.GNP.ATLS.CD

Population Indicators, German Federal Statistical Office, Web, 25 October 2010. Retrived from: http:// www.destatis.de/jetspeed/portal/cms/

Voluntary Action in Germany: Facts and Figures, European Volunteering Center, Web, 25 October 2010. Retrived from: http://www.icicp.org/ht/a/GetDocumentAction/i/5534.

Civil Society Sector at a Glance: Germany, 1995," Center for Civil Society Studies, Johns Hopkins University. Retrived from: http://www.ccss.jhu.edu/pdfs/CNP/CNP_Germany_WrkExp.pdf.

Germany Human Development Report, United Nations Development Programme, 2007/2008. Retrived from: http://hdrstats.undp.org/countries/data_sheets/cty_ds_DEU.html. 